\title{
Study of YAP Element among an Endogamous Human Isolate in Punjab
}

\author{
Badaruddoza $^{1}$,A.J.S. Bhanwer ${ }^{1}$, M. Rambani ${ }^{1}$, R. Singh ${ }^{1}$, K. Matharoo $^{1}$ and R.N.K. Bamezai ${ }^{2}$ \\ 1. Department of Human Genetics, Guru Nanak Dev University, \\ Amritsar 143005, Punjab, India \\ 2. National Centre of Applied Human Genetics, SLS, JNU, New Delhi, India
}

KEYWORDS Ahmadiyya; YAP; insertion; Y chromosome

\begin{abstract}
The blood samples of 66 Ahmadiyya Muslim males from Qadian, district Gurdaspur of Punjab have been analysed to study the Y-chromosome $A l u$ insertion polymorphism (YAP). Y-chromosomes carrying the YAP element were found in many populations in India and Pakistan. However, the absence of YAP insertion element in the present Ahmadiyya population has suggested that this isolated population is not likely to have been affected by many migrations in Indian history.
\end{abstract}

\section{INTRODUCTION}

Inspite of the slow initial discovery of polymorphic genetic markers on the Ychromosome (Casanova et al. 1985), it has grown dramatically during recent time for studying human phylogeny at molecular level (Kayser et al. 1997; Prinz et al.1997; Underhill et al. 1997; Vandenberg et al. 1999). The varieties of polymorphic markers are now available on the nonrecombining portion of the $\mathrm{Y}$ chromosome range from base substitution, deletion and insertion etc. Therefore, these polymorphic sites are useful for tracing the origin of paternal lineages in human population (Qamar et al. 1999) and can be often traced among populations within limited geographic areas (Hammer et al. 1998; Jobling and Tyler-Smith 1995, 2000, 2003) and specific ethnic groups (Qamar et al. 1999; Underhill et al. 2001). However, from some large scale surveys of human Y-chromosome polymorphism (Hammer 1994; Hammer et al. 1997; Jobling and Tyler-Smith 1995, 2000, 2003), it has been found a simple and stable polymorphism from the recent insertion of an Alu-family member on the long arm of the $\mathrm{Y}$ chromosome. This element, referred to as the Y Alu polymorphic element is present at a specific site on the Ychromosome in some humans and absent in others. One such Alu insertion is the Y Alu polymorphic element (YAP). This polymorphism

Corresponding Author: Dr. Badaruddoza, Department of Human Genetics, Guru Nanak Dev University, Amritsar 143 005, Punjab, India

E-mail: doza13@yahoo.co.in. is particularly useful because of its low rate of parallel and back mutation, which makes it suitable for identifying stable parental lineages that can be traced back in time over thousands of years.

Here, we report for the first time the YAP element in an isolated endogamous Ahmadiyya Muslim population of Punjab. It is an effort to identify their geographic affinity with their Pakistani counterparts.

\section{MATERIALSANDMETHODS}

The blood samples of 66 Ahmadiyya Muslim males from village Qadian, district Gurdaspur of Punjab where they have their head quarter in India and they form a distinct genetic isolate as their customs are different from other Muslims of India and Pakistan. The samples were collected after getting their written informed consent. About $7 \mathrm{ml}$ venous blood was collected in prelabelled tubes containing 0.5M EDTA as an anticoagulant. The samples were transported on ice to the laboratory and stored at $-20^{\circ} \mathrm{C}$ till further analysis.

DNA was extracted using organic method (Gill et al. 1987) and the amount of DNA in each sample was quantified by electrophoresis on $1 \%$ agarose gel. The DNA samples were amplified for YAP element by Polymerase chain reaction (PCR) using the specific forward primer 5'CAGGGGAAGATAAAGAAATA3' and reverse primer 5' ACTGCTAAAAGGGGATGG AT3'. During PCR initial denaturation was done at $94^{\circ} \mathrm{C}$ for 3 minutes followed by 30 cycles of 
denaturation at $94^{\circ} \mathrm{C}$ for 45 seconds, primer annealing at $48^{\circ} \mathrm{C}$ for 45 seconds and primer extension at $72^{\circ} \mathrm{C}$ for 45 seconds. The final extension step was extended to 5 minutes followed by incubation at $4^{\circ} \mathrm{C}$. After amplification the samples were electrophoresed on agarose gel containing Ethidium bromide for $1 \frac{1}{2}$ hour at a constant voltage of $100 \mathrm{~V}$. The gel was then placed on UV Transilluminator to visualise the results and to take the photograph.

\section{RESULTS AND DISCUSSIONS}

In none of the samples of the present study any YAP+ insertion was found as is shown in figure I. The study was carried out to evaluate the YAP in Muslim isolate population of Punjab since it is believed that all migrations to this part of continent took place from Middle East and Central Asia and in neighbouring Pakistan many groups exhibit this insertion (Qamar et al. 1999; Hammer et al. 1997). In all Middle Eastern Muslim populations the YAP insertion is found to be in the frequency of $11-25 \%$ but none of the North Indian and South Indian population had this insertion (Deka et al. 1996; Al-Zahery et al. 2003).

The absence of YAP insertion element in present Ahmadiyya Muslim isolate validates that there is no paternal lineages connection with Pakistani Muslims, which are reported in the literature with some instances of positive insertion (Qamar et al. 1999; Hammer et al. 1997). In the study of YAP in nine populations of UP, North India, Agrawal et al. (2005) also did not find YAP insertion in any of the population groups, except for the Shia Muslims. Interestingly they did not find it in Sunni Muslims as observed in the present study, despite the fact that both groups have a common origin historically (Agrawal et al. 2005). It also appears that Ahmadiyya Muslims have not been affected by many migrations to Indian subcontinent. However, it is hypothesized that invasions of Aryans, Arabs and Mongols have significantly contributed to the ethnic variety of Indian population. The other population where the YAP insertion is found in very high frequency of $40 \%$ is the Siddis, a population of known East African ancestry found in Southern Andhra Pradesh (Ramana et al. 2001). Whereas, Thangaraj et al. (2003) observed 100\% frequency of Asian specific lineage (D) of YAP, both in Onges and Jarawas population groups of Andaman Islands, though representing the descendents of early colonisers of South East Asia later replaced in most of the continent by Palaeolithic and Neolithic agriculturists. Saha et al. (2005) also screened five regional populations groups of India from Punjab, Uttar Pradesh, Bihar, West Bengal and South India for the YAP polymorphism but could not find this polymorphism in any of the population group. The present study like many earlier studies failed to find any polymorphism of YAP insertion in the Ahmaddiya Muslims. Therefore, further

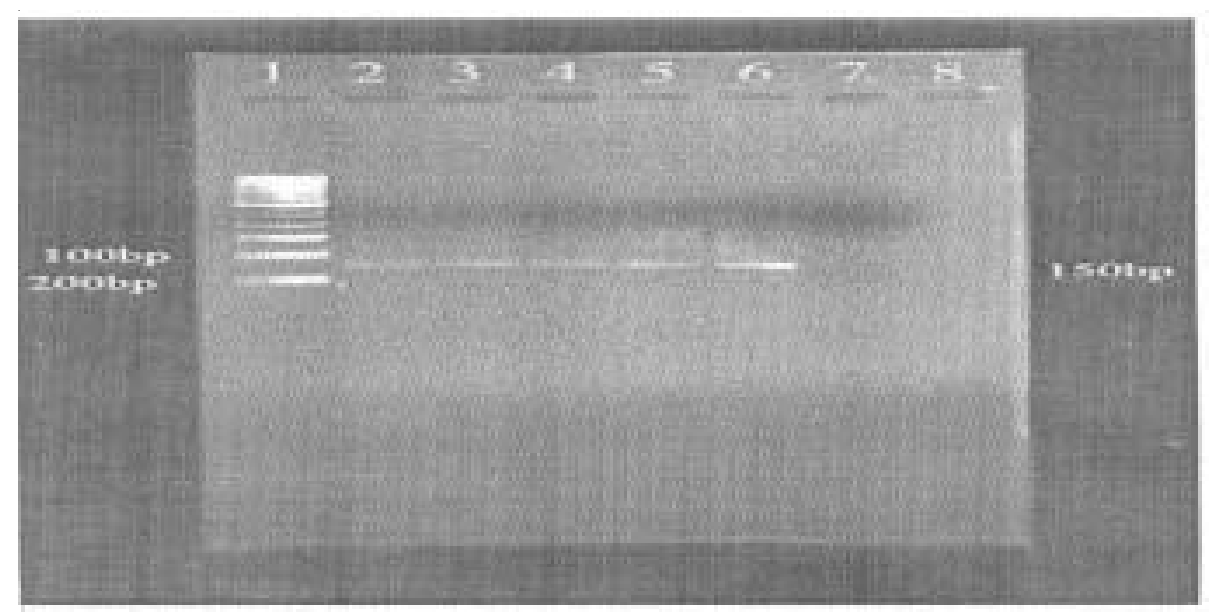

Fig. 1. 2\% Agarose gel picture showing size of PCR products amplified by YAP specific primers. All the bands (lane 2-6) are of 150 bp showing no insertion 
study of Y-chromosome markers, is required in the present population to elucidate in details about the paternal origin of the population groups and know its migration history at the global level.

\section{REFERENCES}

Agarwal S, Khan F, Pandey A, Tripathi M, Herrera RJ 2005. YAP signature of an African-Middle Eastern Migration into Northern India. Current Science, 88: $1977-1980$.

Al-Zahery N, Semino O, Benuzi G, Magri c, Passarino G, Torroni A, Santachiara-Benerecetti AS 2003. Y Chromosome and mtDNA Polymorphism in Iraq, a Crossroad of the Early Human Dispersals and of Post Neolithic Migrations. Mol Phylogenet Evol, 28: $458-472$.

Casanova M, Leroy P, Boueekkini C, Weissenbach J, Bishop C, Fellow M, Purrello M, Fiori G, Siniscalco M 1985. A Human Y-Linked DNA Polymorphism and Its Potential for estimating Genetic and Evolutionary Distance. Science, 203: 1403-1406.

Deka R, Jin L, Shriver MD, Yu LM, Saha N, Barrantes R, Chakraborty R, Ferrell RE 1996. Dispersion of Human Y Chromosome Haplotypes on Five Microsatellites in Global Populations. Genome Res, 6: $1177-1184$

Gill P, Lygo JE, Fowler SJ, Werett DJ 1987. An Evaluation of DNA Fingerprinting for Forensic Purpose. Electrophoresis, 8: 38-44.

Hammer MF 1994. A Recent Insertion of An Alu Element on the Y-Chromosome is a Useful Marker for Human Population Studies. Molec Biol Evol, 11: 749-761.

Hammer MF, Karafet T, Rasanayagam A, Wood ET, Altheide TK, Jenikins T, Griffiths RC, Templton AR, Zegura SL 1998. Out of Africa and Back Again: Nested Cladistic Analysis of Human Y-Chromosome Variation. Molec Biol Evol, 15: 427-441.

Hammer MF, Spurdle AB, Karafet T, Bonner MR, Wood ET, Novelleto A, Malaspina P, Mitchel RJ, Horai S, Jenkins T 1997. The Geographic Distribution of Human Y-Chromosome Variation. Genetics, 145: 787-805.

Jobling MA, Tyler-Smith C 1995. Fathers and Sons: The Y-Chromosome and Human Evolution. Tr Genet, 11: 449-456.

Jobling MA, Tyler-Smith C 2000. New Uses for New
Haplotypes of the Human Y-Chromosome, Disease and Selection. Tr Genet, 8: 356-362.

Jobling MA, Tyler-Smith C 2003. The Human YChromosome: An Evolutionary Marker Comes of Age. Nature, 4: 599-612.

Kayser M, Casglia A, Corach D, Fretwell N, Gehrig C, Graziosi G, Heidorn F, Herrmann S, Herzog B, Hiding M, Honda K, Jobling M, Krawczak M, Leim K, Meuser S, Meyer E, Oesterreich W, Pandya A, Parson W, Penacino G, Perez-Lezaun A, Piccinici A, Prinz, Schmitt C, Roewer L 1997. Evaluation of Y-Chromosome STR's. A Multicenter Study. Int $J$ Legal Med, 110: 125-133.

Prinz M, Boll K, Baum H, Shaler B 1997. Multiplexing Of Y-Chromosome Specific STR's and Performance for mixed Samples. Forensic Sci Int, 85: 209-218.

Qamar R, Ayub Q, Khaliq S, Mansoor A, Karafet T, Mehdi SQ, Hammer MF 1999. African and Levantine Origins of Pakistani $\mathrm{YAP}^{+} \mathrm{Y}$ Chromosomes. Hum Biol, 71: 745-755.

Ramana GV, Su B, Jin L, Singh L, Wang N, Underhill PA, Chakraborty R 2001. Y Chromosome SNP Haplotypes Suggest Evidence of Gene Flow Among Caste, Tribe and the Migrant Siddi Population of Andhra Pradesh, South India. Eur J Hum Genet, 9: 695-700.

Saha A, Sharma S, Bhat A, Pandit A, Bamezai R 2005. Genetic Affinity Among Five Different Population Groups in India Refelecting a Y-Chromosome Gene Flow. J Hum Genet, 50: 49-51.

Thangaraj K, Singh L, Reddy AG, Rao VR, Sehgal SC, Underhill PA, Pierson M, Frame IG, Hagelberg E 2003.Genetic Affinities of Andaman Islanders, a Vanishing Human Population. Curr. Biol. 13: 8693.

Underhill PA, Jin L, Lin AA, Mehdi SQ, Jenkins T, Vollrath D, Davis RW, Cavalli-Sforza LL, Oefner PJ 1997. Detection of Numerous Y-Chromosome Biallelic Polymorphisms by Denaturing High Performance Liquid Chromatography (DHPLC). Genome Res, 7: 996-1105.

Underhill PA, Passarino G, Lin AA, Shen P, Lahr MM, Foley RA, Oefner PJ, Cavalli-Sforrza LL 2001. The Phylogeography of Y-Chromosome's Binary Haplotypes and the Origins of Modern Human Populations. Ann Hum Genet, 65: 43-62.

Vandenberg N, Vanoorschot RAH, Tyler-Smith C, Mitchell RJ 1999. Y- Chromosome-Specific Microsatellite Variation in Australian Aboriginals. Hum Biol, 71: 915-931. 